\title{
Adjuvant EGFR-TKIs-based therapy: are we ready?
}

\author{
Terence Tam \\ Specialist in Respiratory Medicine, Department of Medicine, Queen Mary Hospital, Hong Kong, China \\ Correspondence to: Terence Tam. Specialist in Respiratory Medicine, Department of Medicine, Queen Mary Hospital, Hong Kong, China. \\ Email: tcctam@netvigator.com. \\ Provenance and Peer Review: This article was commissioned by the editorial office, Translational Lung Cancer Research. The article did not undergo \\ external peer review. \\ Comment on: Liang W, Cai K, Chen C, et al. Society for Translational Medicine consensus on postoperative management of EGFR-mutant lung \\ cancer (2019 edition). Transl Lung Cancer Res 2019;8:1163-73.
}

Submitted Mar 06, 2020. Accepted for publication Mar 26, 2020.

doi: $10.21037 /$ tlcr.2020.04.08

View this article at: http://dx.doi.org/10.21037/tlcr.2020.04.08

The increasing use of computed tomography (CT) as an imaging modality coupled with the growing uptake of lung cancer screening program have enabled the medical community to diagnose lung cancer at an earlier stage (1). Surgical resection remains the cornerstone of curative treatment and the advances in surgical techniques have led to an increase in patients undergoing curative operation with favorable short-term outcome $(2,3)$. The substantial risk for post-operative recurrence, however, necessitate the use of adjuvant platinum-based chemotherapy for selected stage IB, and all applicable stage II-IIIA non-small cell lung cancer (NSCLC) patients $(4,5)$.

Epidermal growth factor receptor (EGFR) mutation comprises $\sim 32 \%$ of genomic drivers in NSCLC $(38.8 \%$ in Asian, $17.4 \%$ in Caucasians and $17.2 \%$ in African Americans) and this EGFR positivity appear similar across different stages of disease (34\% in Stage I, 29.9\% in Stage II, $33.8 \%$ in Stage III and $37.5 \%$ in Stage IV) (6). The excellent response, favorable side effect profile and ongoing discovery of newer EGFR-TKIs make them an attractive candidate as a treatment option in the adjuvant setting $(7,8)$. Pooled analysis of data from 1,860 patients that demonstrated an improvement in 2-year disease-free survival (DFS) rate by $~ 50 \%$ certainly support this (9).

Theoretically, however, there exist equally reasonable arguments against EGFR-TKIs-based adjuvant therapy. For one, the rationale for adjuvant cytotoxic chemotherapy lies in its potential to eradicate minimal residual disease (MRD), and studies have shown that tumor can develop rapid cell adhesion response that sacrifices tumor growth to evade the cytotoxic effect of EGFR-TKIs (10). In such instance, the "adjuvant" EGFR-TKIs may only serve to suppress cell growth but would not be able to achieve the desired MRD eradication. Indeed, there are studies that observed rapid disease recurrence upon cessation of adjuvant EGFR-TKIs that seems to support this claim (11).

In this issue of Translational Lung Cancer Research, an international, multidisciplinary panel was established to extensively review the latest available evidence and make recommendations on this much anticipated (and debated) subject. Starting with addressing the role of routine EGFR mutations testing in all surgically resected NSCLC to stratify the risk of post-operative recurrence (12), the author introduced the concept of clinical \& gene panel-based prediction models to assess such risk $(13,14)$. Recurrence risk stratification for patients with expected poor tolerance to chemotherapy formed the basis of the current recommendation of considering EGFR-TKI (in lieu of standard platinum-based chemotherapy) as the chemotherapeutic agent for adjuvant therapy.

The author must be praised in their effort to then soldier on to answer important practical questions, including addressing the rationale and recommendation on the minimum adjuvant EGFR-TKI treatment period (2 years), whether these patients should be monitored differently during therapy (annual MRI brain and bone scan in addition to CT thorax) and the risk (or lack of) T790M induction with the use of adjuvant EGFR-TKI. The final part of the consensus statement touched upon the unfortunate issue of true recurrence and metastasis and covered the pros and cons 
of using archival versus re-biopsy tissue to guide treatment (15), as well as the rationale to retry the original adjuvant EGFR-TKIs in the event of post-adjuvant recurrence (16).

The astute reader will notice that the layout of the paper consists not only of the consensus statements, but also a follow-up section that contain commentaries from invited experts in the field. This is a true testament of the evolving nature of this important issue and the dedication that is required to continue to pursue this further into the future. Notwithstanding this, however, I believe readers will find the consensus paper informative and practice changing.

\section{Acknowledgments}

Funding: None.

\section{Footnote}

Conflicts of Interest: The author has completed the ICMJE uniform disclosure form (available at http://dx.doi. org/10.21037/tlcr.2020.04.08). The author has no conflicts of interest to declare.

Ethical Statement: The author is accountable for all aspects of the work in ensuring that questions related to the accuracy or integrity of any part of the work are appropriately investigated and resolved.

Open Access Statement: This is an Open Access article distributed in accordance with the Creative Commons Attribution-NonCommercial-NoDerivs 4.0 International License (CC BY-NC-ND 4.0), which permits the noncommercial replication and distribution of the article with the strict proviso that no changes or edits are made and the original work is properly cited (including links to both the formal publication through the relevant DOI and the license). See: https://creativecommons.org/licenses/by-nc-nd/4.0/.

\section{References}

1. Goebel C, Louden CL, McKenna R Jr, et al. Diagnosis of Non-small Cell Lung Cancer for Early Stage Asymptomatic Patients. Cancer Genomics Proteomics 2019;16:229-44.

2. Bravo Iniguez $\mathrm{CE}$, Armstrong $\mathrm{KW}$, Cooper Z, et al. Thirty-day mortality after lobectomy in elderly patients eligible for lung cancer screening. Ann Thorac Surg 2016;101:541-6.
3. Baldvinsson K, Oskarsdottir GN, Orrason AW, et al. Resection rate and operability of elderly patients with nonsmall cell lung cancer: Nationwide study from 1991 to 2014. Interact Cardiovasc Thorac Surg 2017;24:733-9.

4. Pignon JP, Tribodet H, Scagliotti GV, et al. Lung adjuvant cisplatin evaluation: a pooled analysis by the LACE Collaborative Group. J Clin Oncol 2008;26:3552-9.

5. Douillard JY, Rosell R, De Lena M, et al. Adjuvant vinorelbine plus cisplatin versus observation in patients with completely resected stage IB-IIIA non-small-cell lung cancer (Adjuvant Navelbine International Trialist Association [ANITA]): a randomised controlled trial. Lancet Oncol 2006;7:719-27.

6. Zhang YL, Yuan JQ, Wang KF, et al. The prevalence of EGFR mutation in patients with non-small cell lung cancer: a systematic review and meta-analysis. Oncotarget 2016;7:78985-93.

7. Wu YL, Zhou C, Hu CP, et al. Afatinib versus cisplatin plus gemcitabine for first-line treatment of Asian patients with advanced non-small-cell lung cancer harbouring EGFR mutations (LUX-Lung 6): an open-label, randomised phase 3 trial. Lancet Oncol 2014;15:213-22.

8. Andrews Wright NM, Goss GD. Third-generation epidermal growth factor receptor tyrosine kinase inhibitors for the treatment of non-small cell lung cancer. Transl Lung Cancer Res 2019;8:S247-S264.

9. Raphael J, Vincent M, Boldt G, et al. Adjuvant Epidermal Growth Factor Receptor Tyrosine Kinase Inhibitors (TKIs) in Resected Non-Small Cell Lung Cancer (NSCLC): A Systematic Review and Meta-analysis. Am J Clin Oncol 2019;42:440-5.

10. Wang HY, Hsu MK, Wang KH, et al. Non-small-cell lung cancer cells combat epidermal growth factor receptor tyrosine kinase inhibition through immediate adhesionrelated responses. Onco Targets Ther 2016;9:2961-73.

11. Zhong WZ, Wang Q, Mao WM, et al. Gefitinib versus vinorelbine plus cisplatin as adjuvant treatment for stage II-IIIA (N1-N2) EGFR-mutant NSCLC (ADJUVANT/ CTONG1104): a randomised, open-label, phase 3 study. Lancet Oncol 2018;19:139-48.

12. He Q, Xin $\mathrm{P}$, Zhang $\mathrm{M}$, et al. The impact of epidermal growth factor receptor mutations on the prognosis of resected non-small cell lung cancer: a meta-analysis of literatures. Transl Lung Cancer Res 2019;8:124-34.

13. Liang $W$, Zhang L, Jiang G, et al. Development and validation of a nomogram for predicting survival in patients with resected non-small-cell lung cancer. J Clin Oncol 2015;33:861-9. 
14. Kratz JR, He J, Van Den Eeden SK, et al. A practical molecular assay to predict survival in resected nonsquamous, non-small-cell lung cancer: development and international validation studies. Lancet 2012;379:823-32.

15. Zhao ZR, Lin YB, Shao YW, et al. Mutation profile of resected EGFR-mutated lung adenocarcinoma by next-

Cite this article as: Tam T. Adjuvant EGFR-TKIs-based therapy: are we ready? Transl Lung Cancer Res 2020;9(4):948-950. doi: $10.21037 /$ tlcr.2020.04.08 generation sequencing. Oncologist 2019;24:1368-74.

16. Pennell NA, Neal JW, Chaft JE, et al. SELECT: A Phase II Trial of Adjuvant Erlotinib in Patients with Resected Epidermal Growth Factor Receptor-Mutant Non-SmallCell Lung Cancer. J Clin Oncol 2019;37:97-104. 